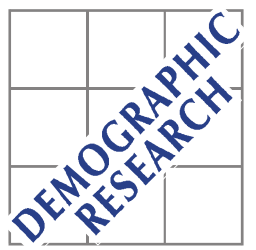

Demographic Research a free, expedited, online journal of peer-reviewed research and commentary in the population sciences published by the Max Planck Institute for Demographic Research Konrad-Zuse Str. 1, D-18057 Rostock · GERMANY www.demographic-research.org

DEMOGRAPHIC RESEARCH

VOLUME 27, ARTICLE 28, PAGES 835-852

PUBLISHED 20 DECEMBER 2012

http://www.demographic-research.org/Volumes/Vol27/28/

DOI: $10.4054 /$ DemRes.2012.27.28

Research Article

Economic uncertainty and family dynamics in Europe: Introduction

\title{
Michaela Kreyenfeld
}

Gunnar Andersson

Ariane Pailhé

(C) 2012 Kreyenfeld, Andersson \& Pailhé.

This open-access work is published under the terms of the Creative Commons Attribution NonCommercial License 2.0 Germany, which permits use, reproduction \& distribution in any medium for non-commercial purposes, provided the original author( $(s)$ and source are given credit. See http:// creativecommons.org/licenses/by-nc/2.0/de/ 


\section{Table of Contents}

Contributions to the Special Collection on Economic Uncertainty and 836 Family Dynamics in Europe

$1 \quad$ Background

2 Historical perspectives on economic conditions and family dynamics

3 Economic uncertainty and fertility during the 20th century 838

$4 \quad$ Is economic uncertainty a major cause of fertility change in the new 842

$5 \quad$ Different uncertainties, different contexts 843

6 Review of contributions to the special collection 844

$\begin{array}{llr}7 & \text { Conclusions } & 847\end{array}$

$8 \quad$ Acknowledgements $\quad 849$

References $\quad 850$ 


\title{
Economic uncertainty and family dynamics in Europe: Introduction
}

\author{
Michaela Kreyenfeld ${ }^{1}$ \\ Gunnar Andersson ${ }^{2}$ \\ Ariane Pailhé ${ }^{3}$
}

\begin{abstract}
Background

Economic uncertainty has become an increasingly important factor in explanations of declining fertility and postponed family formation across Europe. Yet the micro-level evidence on this topic is still limited.
\end{abstract}

\section{Objective}

This special collection of Demographic Research focuses on the issue of how economic and employment uncertainties relate to fertility and family dynamics in Europe.

\section{Methods}

The collection is comprised of studies that explore how various dimensions of employment uncertainty, such as temporary working contracts and individual and aggregate unemployment, are related to the fertility and family formation of women and men across Europe. The studies cover Germany, the UK, France, Russia, Estonia, Sweden, Italy, Spain, and Israel.

\section{Results}

The various micro-level studies that are assembled in this special collection do not provide a simple answer to the question of whether and how economic uncertainty suppresses (or stimulates) fertility. However, some systematic variation by welfare state regime is discernable.

\section{Conclusions}

Given the recent economic volatility in Europe, we expect that labor market uncertainties will remain an important component of explanations of fertility developments in the 21 st century.

\footnotetext{
${ }^{1}$ Max Planck Institute for Demographic Research (MPIDR). E-mail: Kreyenfeld@ demogr.mpg.de.

${ }^{2}$ Stockholm University Demography Unit (SUDA).

${ }^{3}$ Institut national d'études démographiques (INED).
} 


\section{Contributions to the Special Collection on Economic Uncertainty and Family Dynamics in Europe}

1. Berkay Özcan, Karl Ulrich Mayer and Joerg Luedicke (Germany), The Impact of Unemployment on the Transition to Parenthood

2. Ina Berninger, Bernd Weiß and Michael Wagner (Germany), On the Links Between Employment, Partnership Quality, and the Intention to Have a First Child: The Case of West Germany

3. Christian Schmitt (Germany and the U.K.), Labour Market Integration, Occupational Uncertainties, and Fertility Choices in Germany and the UK

4. Ariane Pailhé and Anne Solaz (France), The Influence of Employment Uncertainty on Childbearing in France: A Tempo or Quantum Effect?

5. Sunnee Billingsley (Russia), Economic Crisis and Recovery: Changes in Second Birth Rates within Occupational Classes and Educational Groups

6. Martin Klesment and Allan Puur (Estonia), Effects of Education on Second Births Before and After Societal Transition: Evidence from the Estonian GGS

7. Karin E. Lundström and Gunnar Andersson (Sweden), Labor-market Status, Migrant Status and First Childbearing in Sweden

8. Elisabetta Santarelli (Italy), Economic Resources and the First Child in Italy: A Focus on Income and Job Stability

9. Daniele Vignoli, Sven Drefahl and Gustavo De Santis (Italy), Whose Job Instability Affects the Likelihood of Becoming a Parent in Italy? A Tale of Two Partners

10. Concetta Rondinelli, Arnstein Aassve, Francesco C. Billari (Italy), Women's Wages and Childbearing Decisions: Evidence from Italy

11. Alicia Adsera (Europe and Spain), The Interplay of Employment Uncertainty and Education in Explaining Second Births in Europe

12. Liat Raz-Yurovich (Israel), Men's and Women's Economic Activity and First Marriage: Jews in Israel, 1987-1995 


\section{Background}

During the 1990s, economic uncertainty became an increasingly important factor in explanations of the decline in fertility and the postponement of family formation across Europe, particularly when the goal was to explain the developments observed in Southern and post-socialist Central and Eastern Europe (e.g., Kharkova and Andreev 2000; Bhaumik and Nugent 2002; Kohler and Kohler 2002; Sobotka 2003). The onset of the economic recession in 2008 sparked renewed interest in the role of economic uncertainty for family dynamics. In light of the subsequent financial and economic volatility across Europe, the relationship between economic conditions and family dynamics has become a major topic of public interest. In early 2009, we identified a need for further micro-level evidence on how insecure economic conditions affect fertility decisions and family dynamics in contemporary Europe. Except for research on Eastern Europe, there was still relatively little empirical research based on micro-level data that addressed these issues. To help close this gap, we organized a workshop on Economic Uncertainty and Family Dynamics, which was held in Berlin in July 2009 at the Wissenschaftszentrum Berlin für Sozialforschung / Social Science Research Center Berlin. The workshop was jointly organized by the Max Planck Institute for Demographic Research (MPIDR), the Stockholm University Linnaeus Center on Social Policy and Family Dynamics in Europe (SPaDE), and the French National Institute for Demographic Studies (INED). The contributions in this special collection of Demographic Research are based on papers presented at the workshop. In this collection of articles, we bring together a range of new micro-level evidence on a topic that will remain high on the agenda of researchers and policy makers for many years to come.

\section{Historical perspectives on economic conditions and family dynamics}

The relationship between economic conditions and fertility has been a longstanding topic of interest in demography and demographic research. As far back as 1798, Malthus addressed this issue in his "Essay on Population," in which he claimed that food supply and population growth were closely interrelated. Although Malthus believed that the chief mechanisms that balanced food supply and population growth were starvation, death, and poverty, he also argued that economic hardship might induce people to delay marriage and childbearing. The idea that people need an adequate economic basis to start a family has also shaped social institutions. In many areas of Western Europe during the $18^{\text {th }}$ and $19^{\text {th }}$ centuries, landless and unskilled 
laborers did not have the option to marry, because they were deemed unable to support a family. This contributed to the "Western European marriage pattern," in which large proportions of the population never married at all. Under this regime, "it [was] necessary for a man to defer marriage until he could establish an independent livelihood to support a family" (Hajnal 1965: 133). When childbearing occurred mainly within marriage, such regulations were efficient in limiting fertility to those who were able to support a family. For historical demographers, economic hardship has remained a decisive factor in explanations for postponed or foregone marriage formation and reduced fertility (see, e.g., Bengtsson and Saito 2000).

The assumption that having a secure economic position is the main prerequisite for having children was, however, severely challenged by the demographic developments that are collectively referred to as Europe's demographic transition. During this transition, industrialization and economic growth were accompanied by rapid declines in fertility. This trend gave rise to a situation in which high income and great wealth were associated with low, rather than high, fertility. The observation that wealthier individuals tended to limit their fertility to a greater extent than others called for new theoretical approaches. Some early researchers speculated that having children may have an inverse effect on social mobility (Brentano 1909: 588; Mombert 1912: 816ff.; Mackenroth 1953: 397ff.). Leibenstein (1975) and Easterlin (1976) drew on social differences in aspirations and the concept of "relative income" to explain variations in fertility. Becker (1960) argued that parents not only choose the number of children (child quantity), but also the time and money they invest in each child (child quality). Becker (1993) assumed that, as income levels rise, the demand for child quality tends to increase to a much greater extent than the demand for child quantity, which together result in a negative relationship between (individual and aggregate) income and fertility. The "quality-quantity trade-off" model has become a cornerstone of family economics. However, because it focuses exclusively on income, the scope of the concept is too limited to explain how economic uncertainty relates to fertility.

\section{Economic uncertainty and fertility during the 20th century}

Economic uncertainty may be understood as an individual risk factor, related to phases in the life course that are characterized by unemployment, part-time work, working on a term-limited contract, or difficulties entering the labor market in the first place (e.g., Mills and Blossfeld 2003; Blossfeld et al. 2005; Blossfeld et al. 2006; Blossfeld and Hofmeister 2006). It may also be conceptualized as an aggregate phenomenon, reflecting general uncertainties felt by all people during, for example, an economic recession (Sobotka et al. 2011). 
An inspection of time series of crude total fertility rates and selected macroeconomic indicators for various countries in Europe during the 20th century gives no immediate indication of strong correlations between aggregate economic conditions and fertility. Figure 1 shows how the total fertility rates during 1900-2010 for three European countries, France, Germany, and Sweden, were affected by events such as the onset of the Great Depression, the oil price shock of the early 1970s, and, in the case of Sweden, the financial crisis of the early 1990s. Except for the latter event, which was specific to Sweden (cf. Andersson 2000), it is hard to detect any clear-cut impact of these economic crises on aggregate fertility trends ${ }^{4}$.

While it is widely accepted among demographers that the Great Depression led to reduced fertility, the relationship between the downturn and the time series of period total fertility is not very clear (Figure 1). It has been shown that the Great Depression explains the relatively high levels of childlessness and late ages at first birth for the cohorts born around 1900 (e.g., Ryder 1980). The fertility responses to the Great Depression suggest that there is no uniform impact of macroeconomic conditions on fertility: economic uncertainties may have had different effects at different stages of the life course. Women and men aged 30 and above who were childless during the Great Depression might have had to forgo childbearing in some cases, while younger people had the option of postponing their fertility plans until circumstances improved (Kiser and Whelpton 1953). The relationship between the fertility changes of the 1970s and another big economic downturn, which started with the oil price shock at the beginning of the decade, has attracted relatively little attention from demographers. Fertility developments during this period are more often ascribed to factors other than the macroeconomic conditions. In particular, the Second Demographic Transition theory attributes the fertility declines in Europe during the 1970s and adjacent decades to changes in values such as individualization, self-actualization, individual freedom, and women's emancipation (Lesthaeghe 1983, 2010). Van Bavel (2010) has pointed out that even the demographic literature of the 1920s and 1930s tended to place much greater emphasis on the role of changes in values than on the impact of macroeconomic circumstances in explaining the ongoing fertility declines of those decades.

\footnotetext{
${ }^{4}$ The more general economic recession of the early 1990s also appeared to have had a moderate impact on fertility trends in France: in 1993, the total fertility of France reached its lowest level since the Second World War (1.66).
} 
Figure 1: Total Fertility in France, Germany, and Sweden, 1900-2010

France

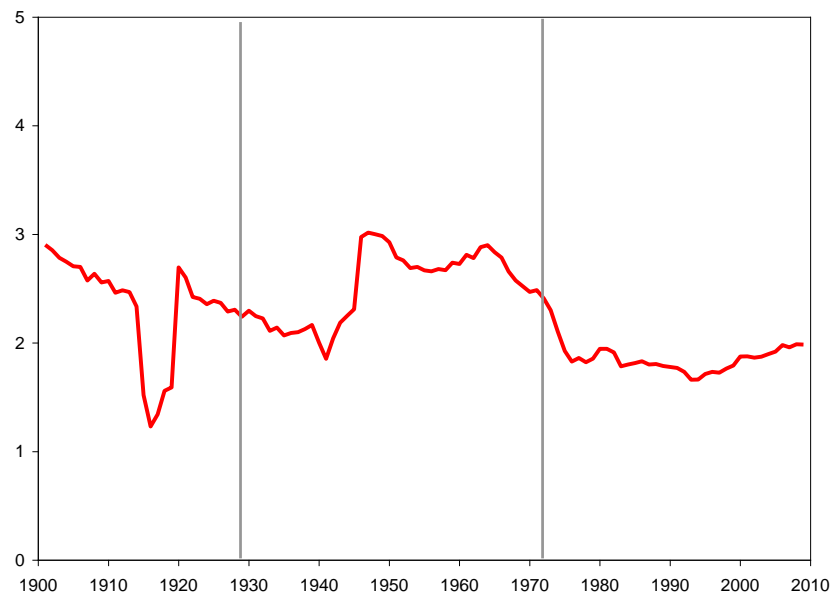

\section{Germany}

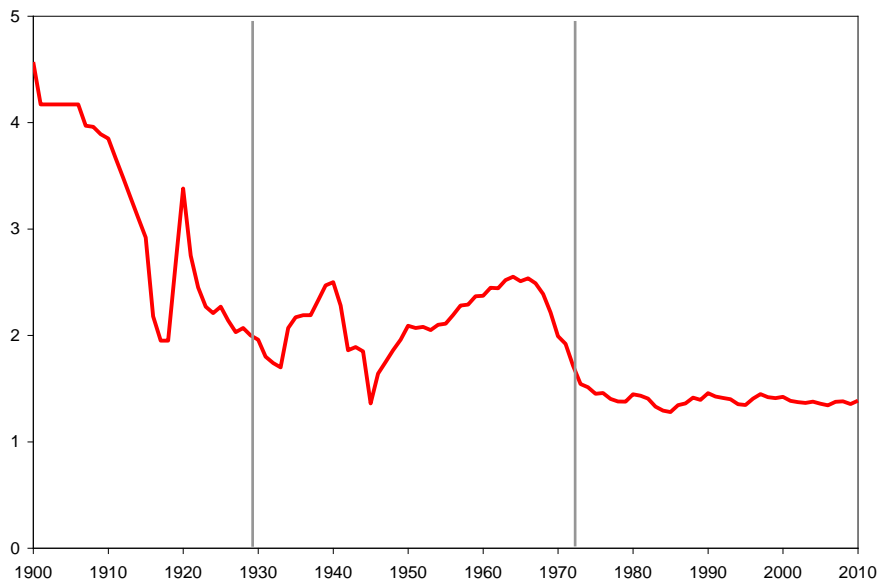


Figure 1: (Continued)

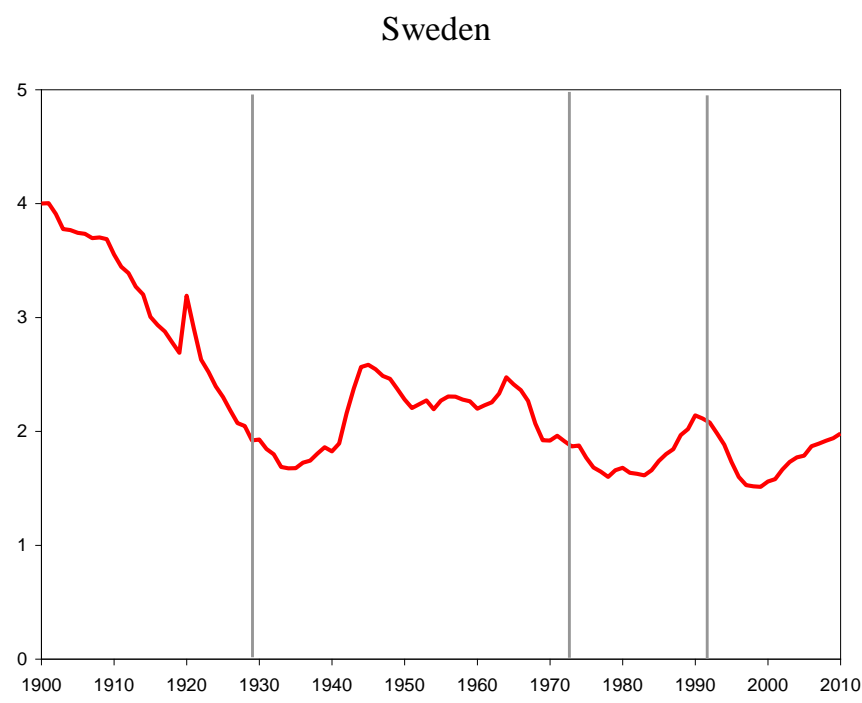

Source: French National Statistical Institute (INSEE), Statistics Sweden (SCB), Schwarz (1997), Human Fertility Database (www.humanfertility.org).

Notes: After 1945 Germany is represented by West Germany. First gray bar: Great Depression (1929); Second gray bar: Oil Price Shock (1973); Third gray bar: Swedish financial crisis (1992).

When seeking to understand the relationship between individual-level circumstances and childbearing and other family-related outcomes, empirical studies have tended to focus on the interplay of women's employment and family dynamics. Many studies are based on economic approaches that assume that women's education and employment increase the opportunity costs of childrearing, which in turn leads to decreasing fertility (Lehrer and Nerlove 1986; Becker 1993: 140; Engelhardt and Prskawetz 2004). Sociological approaches refer to similar mechanisms as evidence of "role incompatibility". Both the economic approach to fertility and the Second Demographic Transition theory posit that women's emancipation and employment are detrimental to fertility. However, neither of these two lines of thought adequately consider the possibility that labor market uncertainties are determinants of childbearing and family-demographic behavior. 


\section{Is economic uncertainty a major cause of fertility change in the new millennium?}

More recently, demographers have paid increasing attention to economic uncertainty as a potential cause of the fertility declines observed across Europe since the 1980s. The observation of correlations in some countries between low fertility at the macro level and adverse economic conditions has spurred this interest. First, Southern Europe experienced drastic declines in annual birth rates during the 1990s. Some researchers have suggested that the segmentation of Southern Europe's labor markets, which are characterized by high levels of youth unemployment and precarious patterns of entry into employment, fuelled the fertility declines of these countries (McDonald 2000: 10f.; Gonzalez and Jurado-Guerro 2006). Second, in Central and Eastern Europe, birth rates declined rapidly with the dismantling of the communist regimes of the region. The growing uncertainties in labor markets that accompanied the transformation from planned to market economies have been regarded as a chief determinant of the fertility declines of this region (Eberstadt 1994; Witte and Wagner 1995; Ranjan 1999). Furthermore, growing insecurity has come to be seen as a general characteristic of modern societies, caused by deregulation, internationalization, and globalization (e.g., Blossfeld et al. 2006; Blossfeld and Hofmeister 2006). It is often assumed that the increasing uncertainties that young adults face "seep into the partnership and parenthood domains of their lives" (Mills and Blossfeld 2005: 1). Increasing youth unemployment, the prevalence of term-limited working contracts, and unstable employment situations are now viewed as the primary forces behind the postponement of childbearing in contemporary Europe.

While the first decade of the new millennium witnessed moderately increasing fertility rates in countries across Europe (Goldstein et al. 2009), policy makers in many countries still see their current fertility levels as alarmingly low. Consequently, the search for the determinants of the very low fertility observed in large parts of Europe remains high on demographers' research agenda. More recently, the onset of the financial crisis and economic volatility in Europe in 2008 has fuelled interest in how economic uncertainty relates to fertility and family dynamics.

The present collection does not primarily aim to provide analyses of how macroeconomic stress and economic recessions are related to fertility; for more information on that topic, we refer the reader to an excellent review article by Sobotka and colleagues (2011). Instead, we have identified a lack of empirical research on how different dimensions of individual-level economic uncertainty and precarious labor market situations, including those specific to local economic contexts, are related to childbearing and family formation. The purpose of our collection is to provide more empirical evidence on this subject. 


\section{Different uncertainties, different contexts}

All of the contributions to this collection provide micro-level evidence on different aspects of economic and employment uncertainty-e.g., employment status, stability of employment contract, level of and variation in income-and their relationships to family formation and fertility in different contexts in Europe. Almost all of the studies focus on various dimensions of fertility as the outcome variable of interest; e.g., the transition to first and higher order births, fertility intentions, and completed fertility; with one study examining marriage formation.

The contributions look at different aspects of economic and employment uncertainty. A few studies focus on the role of (women's and men's) individual unemployment in childbearing decisions; others also incorporate the role of aggregate unemployment in childbearing behavior, and thus analyze the interplay between individual and macroeconomic uncertainties. A decisive contribution of the present collection is that it provides ample evidence for the importance of several related factors for family formation, including temporary contracts and other aspects of precarious und unstable employment.

A major contribution of the collection is that all of the studies take into account the labor market conditions of both women and men in their analyses of how economic uncertainty relates to family formation. Clearly, this provides valuable insight into the degree to which the relationship between employment uncertainty and family formation differs by gender in different contexts in Europe. Indeed, women's employment has become an increasingly important dimension for understanding the relationship between economic uncertainty and family formation. In the past, it was widely believed that women's work was detrimental to fertility; in contemporary societies, however, work and family life have become more compatible as societies have increasingly had to make accommodations for the needs of dual-breadwinner families. In these societies, we may expect that a stable employment situation for both the man and the woman has become a prerequisite for family formation.

Although several studies included in the collection apply similar variables in their analyses, the outcomes sometimes differ between countries. Some of these differences are explained by the fact that the European countries covered in the collection belong to different welfare state and gender regimes. We expect the role of a man or a woman in an insecure employment situation to differ by context. Indeed, a major strength of our collection is that it can draw on the rich contextual variation of Europe in terms of institutional settings and the cultural and historical backgrounds of different countries. Our collection provides contributions from conservative, universalistic, and liberal welfare states; from post-socialist countries in transition; and from familialistic countries in Southern Europe. Consequently, it provides an up-to-date overview of the 
state of affairs in contemporary Europe. The articles of the collection are organized by the geography of countries that are covered. The first articles focus on Germany, at the center of Europe; we then move on to the U.K. and France in the West, Russia and Estonia in the East, Sweden in the North, and Italy and Spain in the South. We conclude with a study on Israel.

\section{Review of contributions to the special collection}

Berkay Özcan, Karl Ulrich Mayer, and Jörg Lüdicke investigate the association between unemployment and first birth behavior in Germany. Germany is a particularly interesting case to consider if the goal is to gain a better understanding of the relationship between economic uncertainty and fertility. While the western part of the country has enjoyed rather stable economic conditions, East Germans were exposed to severe labor market uncertainties after the demise of the communist system of the GDR. The strong association between high unemployment and low fertility, which can be found at the aggregate level for East Germany, seems to support the idea that adverse economic conditions produce reduced fertility. Using recent data from the German Life History Survey, Özcan and colleagues challenge this view. They focus on men and women born in 1971, who make up the first "post-reunification cohort," having entered their reproductive lives after German unification. The East Germans of this cohort started their employment careers during the phase of major reconstruction of the East German labor market. It might be expected that economic uncertainties would emerge as a major driving force behind East German fertility postponement. However, evidence at the micro level is far from conclusive. Women's unemployment seems to be positively associated with first birth rates in East Germany, while men's unemployment is largely unrelated to the transition to first parenthood.

Ina Berninger, Bernd Weiss, and Michael Wagner also address the German case. However, they are interested in the linkage between employment uncertainties, partnership quality, and fertility intentions. Data for their investigation come from the first wave of the German Generations and Gender Survey conducted in 2005. Using path analysis, they show that job security influences the fertility intentions of male respondents. Men who evaluate the security of their jobs more positively are also more likely to say they want to have a child. However, the association is only indirect: a secure economic position influences the conflict behavior in a partnership, and a nonproblematic conflict situation is positively correlated with the desire to have children. The study also finds a positive effect of the man's income on the desire to have a first child. For the woman's employment characteristics, no similar associations are found. This study therefore supports the idea that (West) Germany remains a male breadwinner 
regime, in which the economic position of the man is most decisive for fertility choices, while the economic situation of the woman is subordinate.

Drawing on prospective survey data from the U.K. and Germany, Christian Schmitt provides a cross-national comparison of the association between various economic conditions and first birth propensities. With this comparison, he contrasts the behaviors in two distinct welfare state regimes. While Germany used to be the prototype of a conservative welfare state regime, the U.K. is the only country in Europe that can be labeled a liberal market regime. In this system, market forces are the overarching allocation mechanism. Family policies are marginal and mainly geared towards providing low-level benefits to alleviate the needs of disadvantaged subgroups of the population. Schmitt shows that the economic determinants of fertility are slightly different in these two contexts. Declining incomes among men, which signals reduced breadwinner capabilities, prevents men from starting a family, but only in Germany. The role of women's employment in fertility is ambiguous, as a woman's unemployment seems to foster her fertility transitions, particularly in the U.K. Overall, the study suggests that the family behaviors observed in the U.K. are quite similar to those that prevail in a conservative welfare state, despite the fact that family policies in this country are not openly geared towards supporting a specific family model.

Ariane Pailhé and Anne Solaz investigate how economic uncertainties, especially unemployment, affect fertility decisions in France. While France is usually praised for providing a high degree of compatibility of work and family life, the French labor market also grapples with high youth unemployment rates. The French experience may therefore be instructive for understanding how uncertainties in the early employment career affect fertility decisions. The authors investigate the ways in which economic uncertainties, such as individual unemployment among men and women, affect fertility postponement. They raise the question of whether uncertainties merely delay fertility, or whether the experience of unemployment has enduring effects in terms of foregone fertility. Using data from the French Family and Employer Survey from 2005, they find that male unemployment results in postponed fertility. However, only long-term unemployment eventually results in reduced lifetime fertility.

Sunnee Billingsley's contribution on fertility behavior in the Russian Federation addresses the fertility dynamics in a country that has experienced severe economic uncertainties during the course of restructuring of its economy after the dismantling of communism. The Russian case is of particular interest, as Russians have continued to have the first child relatively early in the life course, despite being exposed to economic distress. In Russia, the most critical fertility progression has turned out to be the decision to have a second child: second birth rates declined radically at the beginning of the 1990s. In her contribution, Billingsley focuses on the developments of second birth progressions over calendar time. She draws on the Russian Generations and Gender 
Survey, which she links to the related Education and Employment Survey. Billingsley's main interest is in whether second birth rates have taken on different trends for different educational and occupational groups in Russia. It may be assumed that occupational groups that profited more from the recovery of the Russian economy during the early 2000s have experienced higher second birth rates in recent years. This hypothesis is refuted, however, as no major differences in time trends by level of education or occupational group were found. The preceding uniform decline in second births for women and men with different earning power during the 1990s may indicate that the economic constraints and uncertainty that accompanied the crisis were widespread and affected all social groups equally.

Using data from the Estonian Generations and Gender Survey, Martin Klesment and Allan Puur also address the transition to the second child in a post-communist country. They investigate how women's and men's educational attainment is related to second birth intensities in Estonia, and how these relationships have changed over time. They find that both women's and men's education is positively associated with second birth rates. However, the associations have changed over time. In particular, women with a tertiary degree had strongly elevated birth rates during the communist era. After the demise of the communist system, second birth rates declined for all educational groups, but the reduction was greatest for highly educated women. Consequently, highly educated women no longer display elevated second birth rates. This finding for Estonia may indicate that career planning has become an increasingly important issue in higher order fertility in post-communist countries in Europe.

The following study by Karin Lundström and Gunnar Andersson provides evidence of the role of employment security for first childbearing in Sweden. Using survey data linked to register data, they investigate how employment characteristics, such as unemployment or temporary work contracts, influence the transition to first mother- and fatherhood. Compared to other countries covered in the collection, the results for Sweden are quite clear-cut. A precarious employment situation, such as nonemployment or having a temporary working contract, reduces the transition rates to first parenthood. This finding holds for both sexes equally, and is largely applicable to groups of immigrants as well. The results may be interpreted against the background of the Swedish welfare state, including policies such as parental leave benefits, which provide incentives for both sexes to become established in the labor market before having children.

Analyzing couple data for Italy, Elisabetta Santarelli also studies first birth behavior using panel data from the European Community Household Panel. In contrast to the findings for Sweden, she shows that women's employment is negatively associated with transitions to first motherhood. Couples in which the woman is not in the labor market have the highest first birth rates. This result is supported by the study 
of Daniele Vignoli, Sven Drefahl, and Gustavo De Santis, who also investigate the "Italian case" from a couple perspective using recent data from EU-SILC. In line with the findings of Santarelli, they show that women who are not in the labor force experience elevated first birth rates. In general, these findings could be seen as evidence that Italy remains a traditional society in which the man's economic position determines the timing of having a first child. However, further analyses by Vignoli and his colleagues challenge this interpretation. They show that term-limited working contracts delay fertility, regardless of whether it is the man or the woman in a couple who has temporary rather than permanent employment. The authors argue that employment stability is equally important for prospective Italian mothers and fathers.

The study conducted by Concetta Rondinelli, Arnstein Aassve, and Francesco Billari also addresses the situation in Italy. While the two other Italian studies focus on employment participation and unstable employment situations, this study addresses the role of (predicted) women's wages in first, second, and third birth decisions. The study supports the notion that the Italian family system is rather traditional, in that women's earning power translates into low fertility. However, there are variations in patterns by birth order and region in Italy. The detrimental effect of high women's wages on fertility is most pronounced in terms of postponement of first childbearing. The magnitude of the effect is less strong for higher order births, and it varies by region: in Southern Italy, where public daycare is less readily available, women's wages negatively affect higher order fertility, while this is not the case in Northern Italy.

The study by Alicia Adsera provides evidence of the link between employment uncertainty and second birth propensities in 12 European countries. Adsera's study is based on data on labor market careers and childbearing histories from the European Community Household Panel that are linked to macroeconomic time series on unemployment in these countries. Attention is given to the impact of term-limited working contracts, individual unemployment, and aggregate unemployment on second birth rates. She shows that women who hold temporary work contracts delay the transition to the second child. This association varies, however, by level of education. Highly educated women in particular seem to postpone their fertility plans when they are affected by temporary employment. An in-depth analysis of Spain corroborates these findings.

Finally, Liat Raz-Yurovich investigates the economic determinants of marriage formation in Israel. While focusing on marriage, she adds a context of high fertility and the all-encompassing labor market integration of women to the geographies covered by our collection. Analyzing high-quality register data on employment histories and changes in civil status, she shows that the employment stability of both women and men is positively associated with their propensities to form a first marriage. This could be interpreted as meaning that women's and men's employment situations are equally 
important for family formation in Israel. However, further analyses that also take into account the role of earnings show that the income position of men is still more important in decisions on marriage formation than the income of women. While Israeli society may be relatively gender equal in terms of women's integration into the labor market, the traditional understanding of gender roles still appears to be decisive in patterns of family formation.

\section{Conclusions}

The articles of this special collection of Demographic Research all rest on the assumption that economic uncertainties are important determinants of family formation and fertility in contemporary Europe. Some contributions seek to investigate the association between adverse macroeconomic conditions and the downward fertility trends that have been observed for a number of countries in Europe. Several contributions focus on changes in gender roles, and aim to provide insight into how the new roles of women and men in contemporary societies shape the uncertainty and fertility nexus. As women have become firmly established in the labor market, the employment of mothers has, in most countries, become a matter of fact. When the dualearner family model dominates the picture, the association between economic conditions, economic uncertainty, and fertility may become less ambivalent than it was before. Contrary to the situation in societies dominated by the male breadwinner family model, the association is no longer exposed to the opposing forces of the effects of women's and men's employment situations. Indeed, as some countries-most recently, Germany-have implemented family policy regulations that provide incentives for women to become established in the labor market before having children, any positive correlation between economic conditions and family formation may have been intensified.

The various micro-level studies that are assembled in this special collection do not provide a simple answer to the question of whether and how economic uncertainty suppresses (or stimulates) fertility. Clearly, the evidence differs according to the different combinations of country, gender, birth order, and degree of employment uncertainty that are studied. Some conclusive patterns are still discernable. In particular, observed gender differences in the association between economic conditions and family formation support the idea that social policies and institutional factors mediate the relationship between economic uncertainty and family formation. For example, for countries such as Germany and Italy - the prototypes of a conservative and a familialistic welfare state, respectively - it has generally been shown that the economic standing of the man matters more in the fertility decisions of a couple than that of the 
woman. However, we have observed some recent trends towards more egalitarian gender roles among younger cohorts, even in countries like Germany and the UK, i.e., countries that have not traditionally supported gender equality. These findings call for more in-depth research.

Some results point to the importance of considering different dimensions of economic uncertainty, both in terms of individual circumstances and of aggregate measures that reflect the (lack of) opportunities in society. Clearly, there is no simple correlation between economic uncertainty and family formation that can be captured by a single variable. Much previous research has focused on the role of unemployment as an indicator of economic uncertainty, with different mechanisms of effects on family formation of individual and aggregate unemployment. Other factors, such as the role of temporary working contracts or the subjective perception of the employment situation, had not been considered in a systematic manner. The availability of variables on these dimensions of economic and employment uncertainty in several recent surveys has broadened our understanding of the relationship between labor market uncertainties and fertility. Still, some studies have problems related to the fact that many surveys provide relatively small samples of individuals for analysis. This sometimes makes it difficult to provide robust results when the association between economic conditions and fertility are studied for different strata of the populations, as defined by their birth order, life course stage, and other dimensions of social status.

Given the recent economic volatility in Europe, we expect that labor market uncertainties will remain an important component in explanations of fertility developments in the new millennium. Although the data presented here were collected before the last economic recession, the evidence provides valuable insights into what we can expect to see in the wake of it. We hope that our collection of articles will provide inspiration for further research on this important topic.

\section{Acknowledgements}

We are grateful for financial and practical support from the Max Planck Institute for Demographic Research in helping us to organize the workshop on Economic Uncertainty and Family Dynamics, held in Berlin in July 2009. 


\section{References}

Andersson, G. (2000). The impact of labour-force participation on childbearing behavior: Pro-cyclical fertility in Sweden during the 1980s and the 1990s. European Journal of Population 16(4): 293-333. doi:10.1023/A:10064 54909642 .

Becker, G. (1960). An economic analysis of fertility. In: Becker, G. (ed.), Demographic and Economic Change in Developed Countries. Princeton: Princeton University Press: 209-231.

Becker, G. (1993). An Economic Analysis of Fertility: The Economic Approach to Human Behavior. Chicago: University of Chicago Press.

Bengtsson, T. and Saito, O. (2000). Population and Economy: From Hunger to Modern Economic Growth. Oxford: Oxford University Press.

Bhaumik, S. and Nugent, J. (2002). Does economic uncertainty have an impact on decisions to bear children? Evidence from Eastern Germany. Rostock: Max Planck Institute for Demographic Research. (MPIDR Working Papers WP-2002037)

Blossfeld, H.-P., Klijzing, E. Mills, M. and Kurz, K. (2005). Globalization, Uncertainty and Youth in Society. London/New York: Routledge.

Blossfeld, H.-P., Mills, M. et al. (2006). Globalization, Uncertainty and Men's Careers: An International Comparison. Cheltenham: Edward Elgar Publishing.

Blossfeld, H.-P. and Hofmeister, H. (2006). Globalization, Uncertainty and Women's Careers: An International Comparison. Cheltenham: Edward Elgar Publishing.

Brentano, L. (1909). Die Malthussche Lehre und die Bevölkerungsbewegung der letzten Dezennien. Abhandlungen der historischen Klasse der Königlichen Bayerischen Akademie der Wissenschaften 24(3): 565-625.

Easterlin, R. (1976). The conflict between aspirations and resources. Population and Development Review 2(3/4): 417-425. doi:10.2307/1971619.

Eberstadt, N. (1994). Demographic shocks after communism: Eastern Germany, 198993. Population and Development Review 20(1): 137-152. doi:10.2307/2137633.

Engelhardt, H. and Prskawetz, A. (2004). On the changing correlation between fertility and female employment over space and time. European Journal of Population 20(1): 35-62. doi:10.1023/B:EUJP.0000014543.95571.3b. 
Goldstein, J.R., Sobotka, T. and Jasilioniene, A. (2009). The end of 'lowest-low' fertility? Population and Development Review 35(4): 663-699. doi:10.1111/j.1728-4457.2009.00304.x.

González, M.-J. and Jurado-Guerrero, T. (2006). Remaining childless in affluent economies: A comparison of France, West Germany, Italy and Spain, 19942001. European Journal of Population 22(4): doi:10.1007/s10680-006-9000-y.

Hajnal, J. (1965). European marriage patterns in perspective. In: Glass, D. and D. Eversley (eds.), Population in History: Essays in Historical Demography. London: Edward Arnold: 101-143.

Kiser, C. and Whelpton, P. (1953). Resume of the Indianapolis Study of social and psychological factors affecting fertility. Population Studies 7(2): 95-110. doi:10.2307/2172027.

Kharkova, T. and Andreev, E. (2000). Did the economic crisis cause the fertility decline in Russia: Evidence from the 1994 microcensus. European Journal of Population 16(3): 211-233. doi:10.1023/A:1026539832229.

Kohler, H.-P. and Kohler, I. (2002). Fertility decline in Russia in the early and mid 1990s: The role of economic uncertainty and labour market crisis. European Journal of Population 18(3): 233-262. doi:10.1023/A:1019701812709.

Lehrer, E. and Nerlove, M. (1986). Female labor force behavior and fertility in the United States. Annual Review of Sociology 12(1): 181-204. doi:10.1146/ annurev.so.12.080186.001145.

Leibenstein, H. (1975). The economic theory of fertility decline. Quarterly Journal of Economics 89(1): 1-31. doi:10.2307/1881706.

Lesthaeghe, R. (1983). A century of demographic and cultural change in Western Europe: An exploration of underlying dimensions. Population and Development Review 9(3): 411-435. doi:10.2307/1973316.

Lesthaeghe, R. (2010). The unfolding story of the Second Demographic Transition. Population and Development Review 36(2): 211-251. doi:10.1111/ j.1728-4457.2010.00328..x

Mackenroth, G. (1953). Bevölkerungslehre: Theorie, Soziologie und Statistik der Bevölkerung. Berlin/Göttingen: Springer.

McDonald, P. (2000). Gender equity, social institutions and the future of fertility. Journal of Population Research 17(1): 1-16. doi:10.1007/BF03029445. 
Mills, M. and Blossfeld, H.-P. (2003). Globalization, uncertainty and changes in early life courses. Zeitschrift für Erziehungswissenschaft 6(2): 188-218. doi:10.1007/ s11618-003-0023-4.

Mills, M. and Blossfeld, H.-P. (2005). Globalization, uncertainty and changes in early life courses. In: Blossfeld, H.-P. et al. (eds.). Globalization, Uncertainty and Youth in Society. London/New York: Routledge: 1-24.

Mombert, P. (1912). Über den Rückgang der Geburten- und Sterbeziffern in Deutschland. Archiv für Sozialwissenschaft und Sozialpolitik 34: 794-878.

Ranjan, P. (1999). Fertility behaviour under income uncertainty. European Journal of Population 15(1): 25-43. doi:10.1023/A:1006106527618.

Ryder, N. (1980). Components of temporal variations in American fertility. In: Hiorns, R. (ed.). Demographic Patterns in Developed Societies. London: Taylor \& Francis: 15-54.

Schwarz, K. (1997). 100 Jahre Geburtenentwicklung. Zeitschrift für Bevölkerungswissenschaft 22(4): 481-491.

Sobotka, T. (2003). Re-emerging diversity: Rapid fertility changes in Central and Eastern Europe after the collapse of the communist regimes. Population-E 58 (4-5): 451-486. doi:10.2307/3246652.

Sobotka, T., Skirbekk, V. and Philipov, D. (2011). Economic recession and fertility in the developed world. Population and Development Review 37(2): 267-306. doi:10.1111/j.1728-4457.2011.00411.x.

van Bavel, J. (2010). Subreplacement fertility in the West before the baby boom: Past and current perspectives. Population Studies 64(1): 1-18. doi:10.1080/0032 4720903362806.

Witte, J. and Wagner, G. (1995). Declining fertility in East Germany after unification: A demographic response to socioeconomic change. Population and Development Review 21(2): 387-397. doi:10.2307/2137500. 